\title{
Abundance and use pattern of wildcats of ancient human-modified cattle pastures in northern Iberian Peninsula
}

\author{
José J. Jiménez-Albarral ${ }^{1} \cdot$ Fermín Urra $^{2} \cdot$ Fernando Jubete $^{2} \cdot$ Jacinto Román $^{3} \cdot$ Eloy Revilla $^{3} \cdot$ Francisco Palomares $^{3}$ (D)
}

Received: 10 December 2020 / Revised: 15 September 2021 / Accepted: 22 September 2021 / Published online: 7 October 2021

(c) The Author(s) 2021

\begin{abstract}
The wildcat is typically found in low densities. Here, we estimated wildcat abundance in cattle pastures interspersed between forests in northern Iberian Peninsula, and their patterns of intra-annual and daily use. We censused wildcats three times daily (morning, afternoon, and night) from a car during 4 years in summer season. We also carried out four monthly tracks (two in the morning and two in the afternoon) for a complete year. Overall, we recorded 191 wildcats in pastures and 5 on the road in forest zones. Thirteen different individual wildcats were identified during the summer censuses, but only $29.9 \%$ of the wildcats observed ( $n=196$ ) could be assigned to an individual wildcat. The number of wildcats sighted decreased especially during the last year, when sightings were 52-67\% lower than in previous years. Wildcats were seen significantly more during the morning and night censuses than during the afternoon ones. Estimated annual summer densities in pasture areas ranged between 0.11 and 0.46 sightings $/ \mathrm{km}^{2}$. Throughout the year, wildcats were observed 5.9 times more during summer-autumn than during winter-spring, and they could be observed in any time of the day, but more often close to dusk. It is noteworthy that the ancient human-transformed landscapes for cattle pastures could be an important habitat for wildcats in northern Iberian Peninsula, and conserving these areas should be important to maintaining wildcat populations.
\end{abstract}

Keywords Activity patterns $\cdot$ Cattle pastures $\cdot$ Coat pattern $\cdot$ Abundance $\cdot$ Felis silvestris $\cdot$ Line transect method

\section{Introduction}

The wildcat Felis silvestris is one of two felid species that inhabit the Iberian Peninsula. Although the wildcat is widely distributed in Europe, Africa, and Asia (Yamaguchi et al. 2015), its abundance and density are highly variable (Schauenberg 1981). In the Iberian Peninsula, wildcats may be found throughout the territory (García-Perea 2007); however, its populations are scarce and fragmented (Gil-Sánchez et al. 2020).

Between the 1800s and 1900s, the increase of human pressure led to a decline of wildcat populations across Europe and its extirpation in some countries (Nowell and

Francisco Palomares

ffpaloma@ebd.csic.es

1 Chimeneas, C/Miguel Hernández, 8, 18329 Granada, Spain

2 Asociación de Naturalistas Palentinos, Fuentes de Nava, C/ Vega, 7, 34337 Palencia, Spain

3 Department of Conservation Biology, Estación Biológica de Doñana, CSIC, Isla de La Cartuja, Avda. Américo Vespucio 26, 41092 Sevilla, Spain
Jackson 1996). After the protection of the species, in Europe, it is protected at continental scale by the Appendix II of the Bern Convention (Council of Europe 1979) and the Annex IV of the European Habitats Directive 92/43/EEC (Council Directive 1992); the wildcat has spread recolonizing previous territories (Canters et al. 2005, Lapini and Molinari 2007; Say et al. 2012; Steyer et al. 2016). Nevertheless, the International Union for Conservation of Nature Red List of Threatened Species (IUCN Red List) points at a decreasing trend in the populations (Yamaguchi et al. 2015).

In Europe, the most recent estimates of wildcat density, by camera trapping and DNA analyses of scats or hair, show high variability between habitats and within similar habitats. Densities in forest habitats vary from 0.06 to $0.16 \mathrm{ind} / \mathrm{km}^{2}$ in southeast Spain (Gil-Sánchez et al. 2015) to 0.19-0.42 ind/ $\mathrm{km}^{2}$ in Switzerland (Kéry et al. 2011). In heterogenous habitats (which contain different forest types, shrubs, pastures, etc.) density varies from $0.01-0.17 \mathrm{ind} / \mathrm{km}^{2}$ in southern Spain (Soto and Palomares 2014; Gil-Sánchez et al. 2020) to $0.28-1.36 \mathrm{ind} / \mathrm{km}^{2}$ in Sicily, Italy (Anile et al. 2010, 2012, 2014). In addition to the type of habitat, wildcat abundance and density also likely depend on other factors such as prey 
availability, social organization, season, or human persecution (Lozano 2017).

While it has traditionally been considered a typical forest species (Nowell and Jackson 1996), its habitat preferences and general ecological requirements have not been widely studied (Klar et al. 2008; Monterroso et al. 2009; Oliveira et al. 2018; Gil-Sánchez et al. 2020). Currently, there are records of wildcats found in a great variety of habitats such as different forest types, coastal environments, Mediterranean scrub, wetlands, riparian zones, and agricultural and degraded areas (Lozano 2017). Therefore, habitat heterogeneity would favor wildcats; in fact, it seems that shelter and prey availability are the main factors in their habitat selection (Klar et al. 2008; Lozano 2010; Silva et al. 2013; Beugin et al. 2016; Jerosch et al. 2017, 2018; Anile et al. 2019). For example, heterogeneous habitats such as agricultural landscapes or mosaics with Mediterranean scrubs, pastures, and watercourses are suitable for the species (Monterroso et al. 2009; Jerosch 2018) while it selects negatively the pine forests (Lozano 2010; Anile et al. 2019).

The available information about daily activity patterns for wildcats shows crepuscular and nocturnal habits, presenting maximum activity at dusk (Sundquist and Sundquist 2002). Nevertheless, they can also be observed during the day at any time of year (Liberek 1999). In the Iberian Peninsula, information about activity patterns has been obtained from radio-tracking in northern Spain (Urra 2003), and camera trapping in southeast Portugal (Monterroso et al. 2014) and southeast Spain (Martín-Díaz et al. 2018).

The general aim of this study was to estimate wildcat abundance and use of a habitat not previously studied, the ancient human-created cattle pastures of the Montaña Palentina Natural Park, in the northern Iberian Peninsula. In this area, pastures are interspersed between deciduous forests, and wildcats use them for hunting montane water voles Arvicola scherman (Jubete et al. 2017). We examine how intensively wildcats use the pasture open habitat thought the year and along years, expecting that they use this habitat mainly during the months and year with the highest main prey (water vole) abundance (i.e., in summer-autumn, Ventura and Gosalbez 1990). We also studied the activity pattern on pastures, expecting that they be particularly nocturnal since they may be to exposed to depredation or disturbance (Rodriguez et al. 2020; Ruiz-Villar 2021). Additionally, we also determined the feasibility of individually identifying wildcats observed on pastures by coat patterns, which might help to plan the monitoring of this endangered species in many localities. Furthermore, this study provides useful information for the conservation of a species considered, as a rule, in regression (Yamaguchi et al. 2015).

\section{Methods}

\section{Study area}

The study area was located in Montaña Palentina Natural Park (northern Palencia province, Spain; Fig. 1). This is a mountainous zone with a main valley excavated by the Castillería, Pisuerga, and Areños rivers, and some secondary valleys formed by their affluent streams. The altitude ranges between 975 and 2533 asl, and the average annual rainfall
Fig. 1 Study area. (a) Location of Montaña Palentina Natural Park (in green) in Spain. (b) Limits of Montaña Palentina Natural Park with the survey itinerary in red. (c) Detail of the study area with the complete itinerary for the wildcat survey marked in black and red lines (the red line is the partial itinerary that was only censused at night); visible cattle pastures are marked in green; watercourses in blue and the three locations where censuses started during the summer samplings are indicated with yellow points
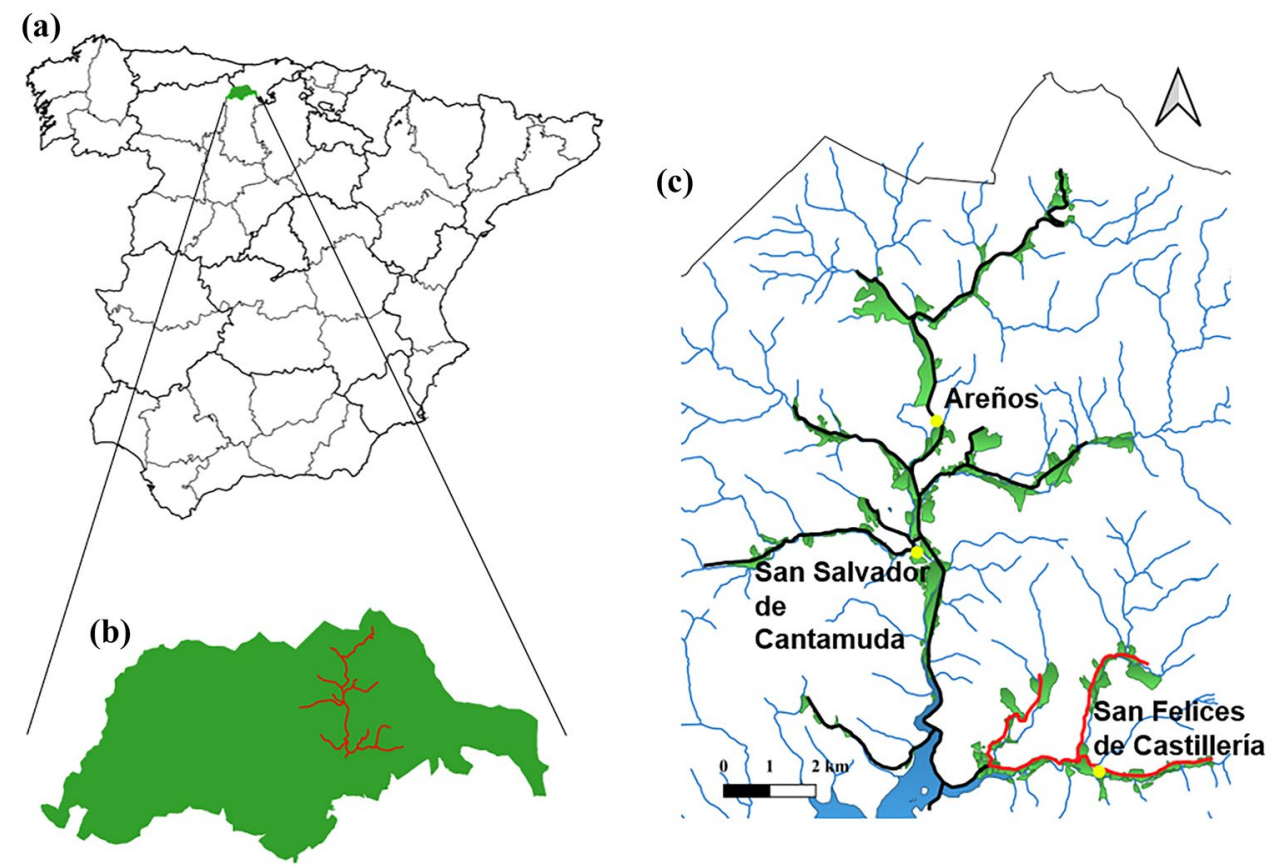
is $674 \mathrm{~mm}$ (Agencia Estatal de Meteorología 2020). The landscape is composed of a series of pastures modified by anthropic action, which together with the natural grasslands make up the so-called tooth and mowing pastures. Heaths of Erica spp, Ulex gallii and Calluna vulgaris, and broadleaf forests of Quercus spp., Fagus sylvatica and Betula pubescens, appear around them. Moreover, some small villages exist in the zone, and extensive livestock and some nature tourists are the main human activities in the area. Livestock uses the pastures mainly from July to August (just after mowing) until normally early winter (depending of snow conditions in the area). Normally, grass on pastures keep short until April/May depending of temperature.

\section{Censusing wildcats}

We used transects for censusing wildcats over seven consecutive days in the summer (late July or early August) from 2016 to 2019, and monthly for 2 days over one complete year between March 2017 and February 2018. The transect or itinerary was undertaken by car on a road running past the valleys of the study area (Fig. 1). At least two people were involved in observations. During the diurnal censuses, driving was done at a speed during of $20-30 \mathrm{~km} / \mathrm{h}$ in the zones with pastures and $40-60 \mathrm{~km} / \mathrm{h}$ in the forested zones since at that part of itinerary probabilities of sighting a cat were very low due to forest cover; during the night censuses, the speed was slower, between 10 and $20 \mathrm{~km} / \mathrm{h}$. Every time a wildcat was observed, we recorded its position on digital maps, which allowed to calculate its distance to the transect road, and if it was possible, it was photographed and/or filmed with a Canon EOS 7D Mark II or a Nikon Coolpix P700 camera (see some examples in Fig. 2).

We traveled two different itineraries (Fig. 1): (1) one complete or diurnal itinerary of $53 \mathrm{~km}$ from San Felices de
Castillería (coordinates UTM: 30 T $381,9714,753,515)$ to Piedrasluengas (coordinates UTM: 30 T 379,873 4,768,718), entering and leaving the secondary valleys, and returning to the same start point. (2) A partial or night itinerary of $10.8 \mathrm{~km}$ restricted to the Castillería Valley; thus, this partial route was included within the complete one. Both itineraries were sampled both going and returning. For the complete itinerary, three different start points (San Felices de Castillería, San Salvador de Cantamuda, and Areños; Fig. 1) were set, which were sequentially rotated during summer censuses, to avoid always sampling the same area at the same time.

Summer censuses were carried out every day in the morning (from approximately $15 \mathrm{~min}$ before sunrise until 10:00-11:05), in the afternoon (from 18:00 to 18:30 until approximately 15 min after sunset), and at night (approximately from 22:30 to 1:00). The complete itinerary was traveled during morning and afternoon censuses, while the partial one was traveled during the night. In 2016, we also carried out the complete itinerary at midday (approximately from 11:00 to 15:00). Time always refers to UTM +1 .

Monthly censuses were carried out 2 days per month traveling the complete itinerary in the morning and in the afternoon periods, although the start times changed over the years according to sunrise and sunset times.

\section{Wildcat identification}

We tried to identify wildcats for all sightings undertaken during the summer censuses. For identification, we used the following (Fig. 2): (1) presence and shape of the gular areola, (2) pattern of the facial lateral lines, (3) pattern of the occipital lines, (4) lateral striped pattern, and (5) pattern of the tail (number, size, and arrangement of the rings). In
Fig. 2 Marks used for the identification of wildcat specimens (a) front view, (b) side view; left panel), and some examples of wildcat photographs taken during the study (right panel) (a)

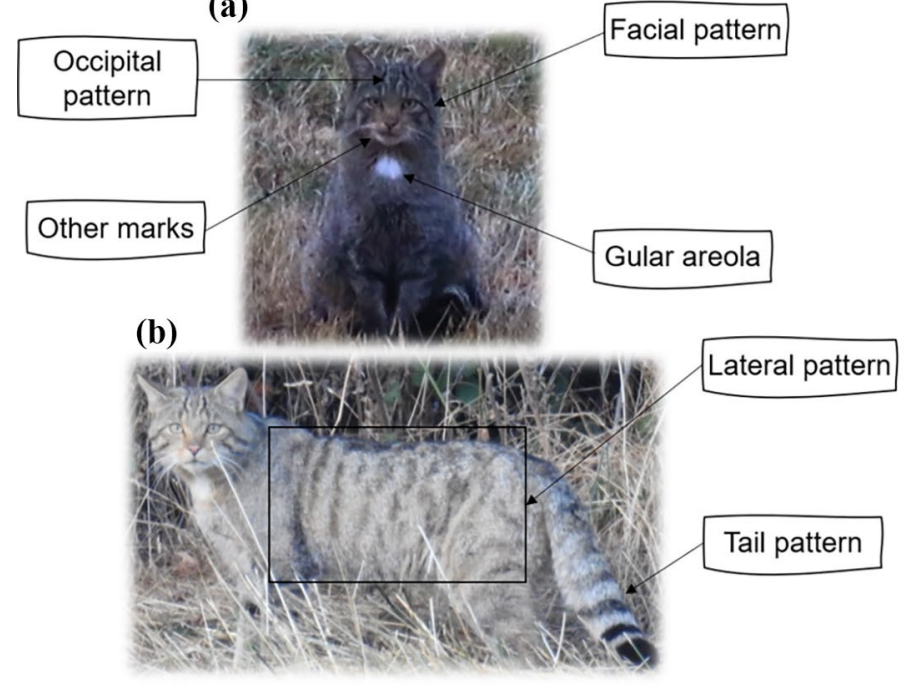

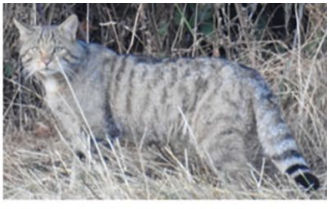
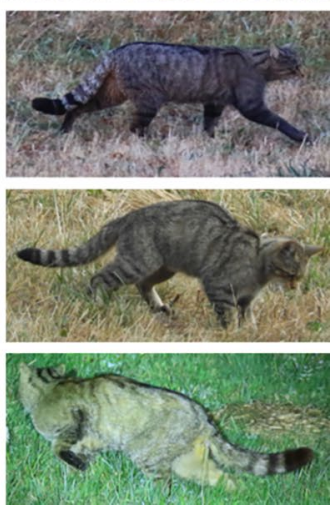
addition, when possible, we also used other marks such as ear cuts or scars when present.

We created a file card for every sighting with the aboveenumerated patterns, and afterward, compared all file cards to determine those that belonged to the same individual.

\section{Data analysis}

Trends in wildcat abundances during summer censuses and along the complete annual monthly censuses were converted by kilometric abundance indexes (IKA; number of sighting of wildcat per $100 \mathrm{~km}$ traveled; Ferry and Frochot 1958), differentiating among day periods when available (morning, midday, afternoon, and night).

Differences between years and day periods for the summer censuses were tested by general linear model (GLM), which included year, day period (morning, afternoon, and night), and their interaction as explanatory variables for both the complete and partial transects. Midday period was not included in analyses since it was only sampled the first year. Post hoc Tukey tests were performed to detect significant differences when the GLM confirmed any significant difference for the variables included in the model. Our sampling unit was the census; therefore, there was a large number of zeros for wildcats sighted, and the only transformation that allowed a GLM was ranking. Thus, the number of wildcats sighted was ranked before performing the GLM test (SAS Institute Inc 2018).

We also estimated wildcat density only for the visible pasture surface actually censused. Visible surface was estimated using Google Street View and posterior checking in the field. A surface area of $7.15 \mathrm{~km}^{2}$ of pasture fields were visible along the complete itinerary and $1.95 \mathrm{~km}^{2}$ in the partial one. In this case, wildcat density was calculated for each day period, using censuses as sampling units. Differences in wildcat density between years and periods were analyzed by GLM with the independent variable transformed to rank for both the complete and partial transects.

Patterns of wildcat daily activity in pastures was estimated hourly using the number of wildcats sighted both during summer and annual censuses. Data were adjusted by the number of times that each hourly period was sampled.

\section{Results}

\section{Data collected}

During the four summer censuses, we performed a total of 91 transects (28 in 2016 and 21 the rest of the years), which means traveling $7283 \mathrm{~km} \mathrm{(2377} \mathrm{km} \mathrm{in} 2016$ and $1635 \mathrm{~km}$ the rest of the years), and wildcats were observed 127 times (41 in 2016, 43 in 2017, 29 in 2018, and 14 in 2019). Of these 127 sightings, only two were not on pastures, and were observed on the road in a forest zone. On the other hand, during the censuses throughout the year, we made 48 transects (5088 $\mathrm{km}$ traveled) and 69 times wildcats were observed, most of them $(95.6 \%)$ on pastures.

\section{Wildcat identifications}

Comparing the cards of all sightings of the summer censuses with records (85 of 127), we identified thirteen different individuals by coat patterns and other identifying marks, in $29.9 \%$ of the sightings (Table 1). Eight wildcats were identified in 2016, six in 2017, five in 2018, and four in
Table 1 Number of cats identified and not identified during the summer censuses

\begin{tabular}{llllllc}
\hline I.D (FS-n ${ }^{\mathbf{0}}$ ) & $\mathbf{2 0 1 6}$ & $\mathbf{2 0 1 7}$ & $\mathbf{2 0 1 8}$ & $\mathbf{2 0 1 9}$ & Total & $\begin{array}{c}\text { Percentage of } \\
\text { total records }\end{array}$ \\
\hline FS-1 & 3 & 5 & 2 & 0 & 10 & 7.87 \\
FS-2 & 1 & 1 & 0 & 0 & 2 & 1.57 \\
FS-3 & 2 & 2 & 0 & 0 & 4 & 3.15 \\
FS-4 & 2 & 0 & 0 & 0 & 2 & 1.57 \\
FS-5 & 1 & 0 & 1 & 0 & 2 & 1.57 \\
FS-6 & 2 & 0 & 0 & 0 & 2 & 1.57 \\
FS-7 & 1 & 0 & 2 & 0 & 3 & 2.36 \\
FS-8 & 1 & 1 & 0 & 1 & 3 & 2.36 \\
FS-9 & 0 & 2 & 0 & 1 & 3 & 2.36 \\
FS-10 & 0 & 1 & 1 & 0 & 2 & 1.57 \\
FS-11 & 0 & 0 & 2 & 0 & 2 & 1.57 \\
FS-12 & 0 & 0 & 0 & 2 & 2 & 1.57 \\
FS-13 & 0 & 0 & 0 & 1 & 1 & 0.79 \\
Identified & 13 & 12 & 8 & 5 & 38 & 29.92 \\
Unidentified & 28 & 31 & 21 & 9 & 89 & 70.08 \\
\hline
\end{tabular}


2019 (Fig. 3). The identified individuals were observed three times on average (range $=1-10$ ). The wildcat most sighted was observed three times in 2016, five in 2017, and two in 2018. Six cats were only observed in 1 year. In the same year, the average straight-line distance between two records of the same cat was $3.3 \mathrm{~km}$ (range $=0.2-9.7 \mathrm{~km}$; Fig. 3), and these were sighted with a time interval of $34 \mathrm{~h} 16 \mathrm{~min}$ (range $=5 \mathrm{~h} 48 \mathrm{~min}-121 \mathrm{~h} 18 \mathrm{~min}$ ).

To associate two or more sightings to the same individual, three of the six coat pattern characteristics considered had to match, unless an identifying mark, such as cuts on the ears or deformations, was visible. In only three of the 85 sightings with records, we were able to find all six types of marks used for identifications; the striped pattern on the sides of the wildcats was the least observed characteristic.

\section{Abundance trends}

Although wildcats can be seen at any time of day, in 2016, wildcat sightings at midday were a rare event $(0.54$ sightings/100 km; Fig. 4); thus, we did not sample at midday for the subsequent years. As previously stated, during the summer censuses, the number of wildcat sightings decreased in the last 2 years, especially in 2019, when sightings were $52-67 \%$ lower than in previous years. IKA by time period also showed this trend, and in 2019, wildcats were less sighted both overall and at any of the time periods sampled except during the afternoon (Fig. 4a, b). Using data from the complete transect, cats were most often sighted during the night, followed by the morning and afternoon periods, except in 2019 when more wildcats were observed during the afternoon period (Fig. 4a). However, using the partial transect, morning and night censuses interchanged positions (Fig. 4b). IKA for the afternoon period were quite stable across years in both cases (Fig. 4a, b). GLM showed statistical significance between years in both cases $(\mathrm{F}=10.1$ and 9.2, respectively, $\mathrm{df}=3, P<0.001$, and pairwise comparisons showed differences between 2019 and the other years; all $p$ 's $<0.05$, although for the partial transect, differences between 2018 and 2019 were not significant, $p=0.417$ ), and between periods $(\mathrm{F}=4.4$ and $4.3, \mathrm{df}=2, P=0.016$ and 0.018 , respectively; pairwise comparison showed statistical differences between night and afternoon periods for the complete transect and between morning and afternoon periods for the partial one, $p=0.011$ and 0.015 , respectively).

For the visible pasture fields actually censused, wildcat abundances ranged between 0.11 and 0.80 sightings $/ \mathrm{km}^{2}$, depending the year and time period (Fig. 4c, d). In this case, wildcat abundance was significantly different among years when using both the complete and partial transects $(\mathrm{F}=9.4$ and 12.7, $\mathrm{df}=3, p<0.001$; lower in 2019 than in the rest of the years, all $p$ 's $<0.016$, for complete transect, but the partial one failed again in detecting significant differences between 2018 and 2019, $p<0.005)$. Similarly, there were significant differences between time periods using both the complete and partial transects $(\mathrm{F}=3.3$ and $5.2, \mathrm{df}=2$, $P<0.043$, respectively), particularly between the night and afternoon period $(p=0.037)$, or afternoon and the other two

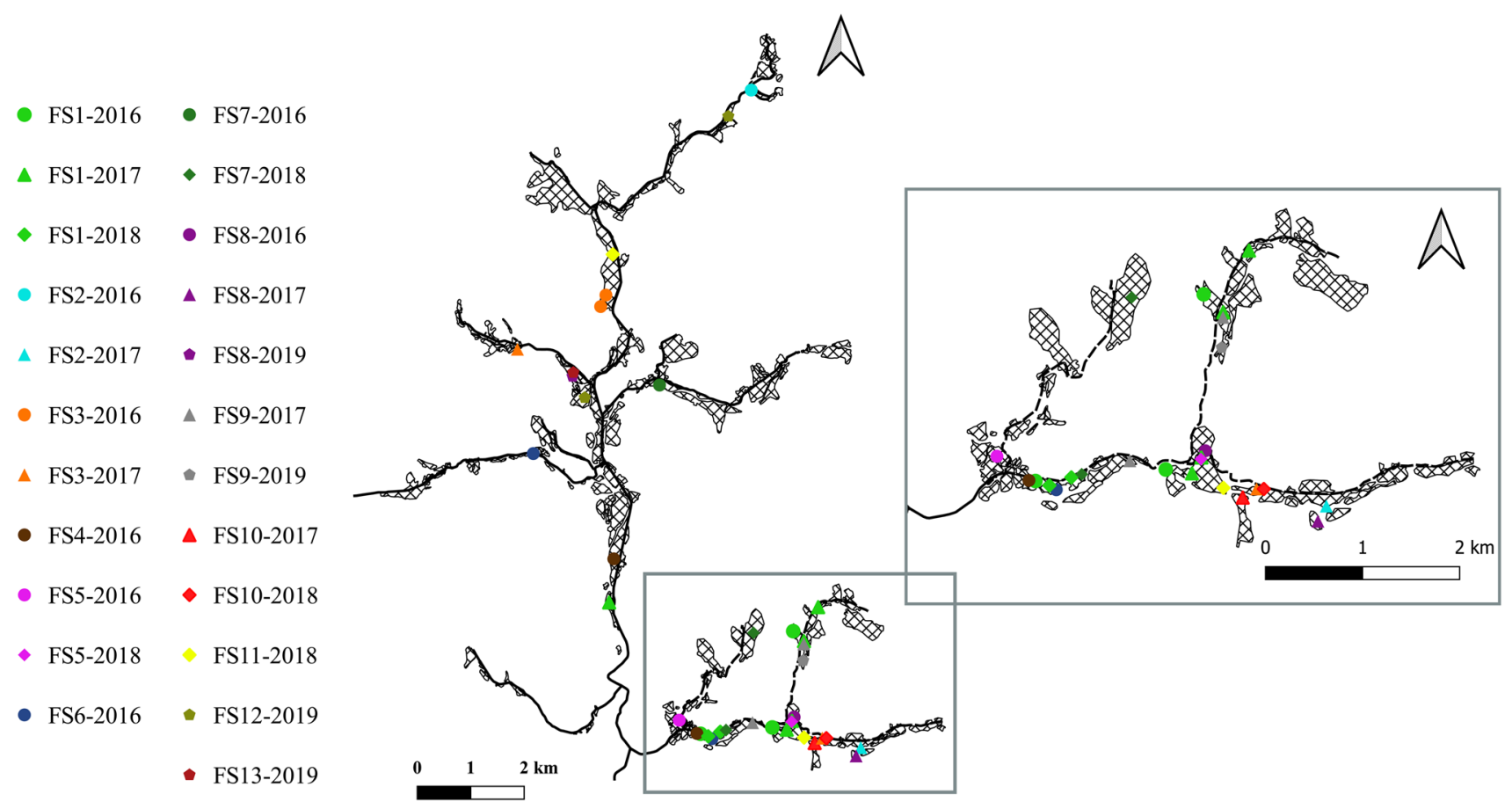

Fig. 3 Location of the sightings of the eleven wildcats identified during the summer censuses of 2016, 2017, 2018, and 2019. The reticulated pattern shows to the visible pastures from roads from where censuses were undertaken 
Fig. 4 IKA values (number of sightings of wildcat $/ 100 \mathrm{~km}$ traveled; $\mathbf{a}$ and $\mathbf{b}$ ) and AI values for visible pastures (Abundance Index: number of sightings of wildcat $/ \mathrm{km}^{2} ; \mathbf{c}$ and $\left.\mathbf{d}\right)$, during summer censuses for each period of the day and the complete (a and $\mathbf{c}$ ) and partial (b and d) transects
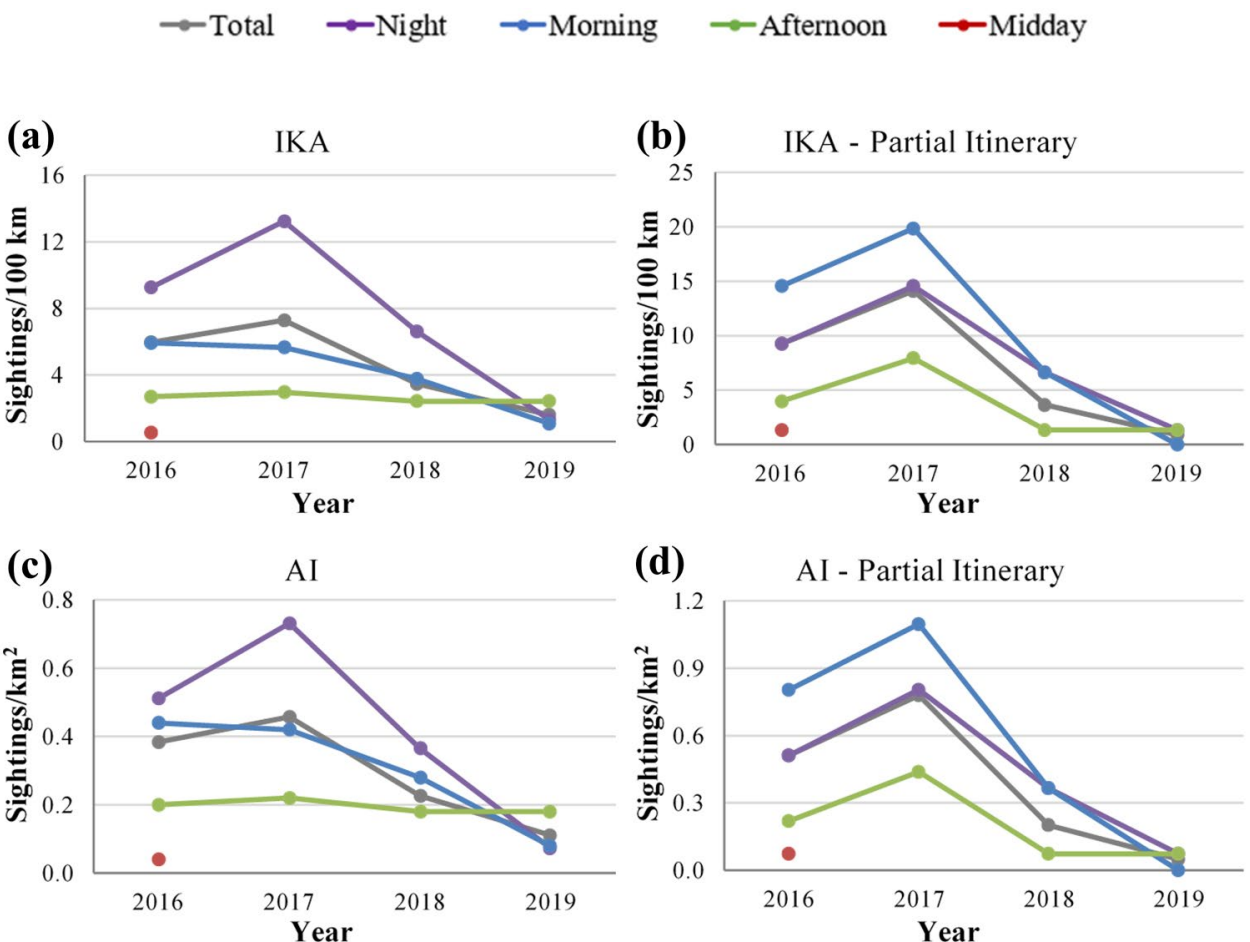

period ( $p=0.025$ and 0.014 for morning and night periods, respectively), for the complete and partial transects, respectively. In all cases, the interaction between the two explanatory variables was not significant $(p>0.05)$.

Censuses throughout the year showed that fewer wildcats were observed from December to June (monthly average $=0.95$ sightings $/ 100 \mathrm{~km}, \mathrm{SE}=0.21$ for overall data) than from July to November, when the number of sightings was 5.9 times higher (monthly overall average $=5.24$ sightings $/ 100 \mathrm{~km}, \mathrm{SE}=1.14 ; \mathrm{W}=0, p=0.005$, Wilcoxon rank sum test with continuity correction; Fig. 5). From June, an increasing tendency was observed peaking in November, when it started to decrease until February (Fig. 5). This pattern was observed both during the morning and afternoon censuses $\left(r_{s}=0.652, p=0.0203 ;\right.$ Spearman rank correlation). On average, the values were slightly higher for the afternoon censuses (1.51 sightings $/ 100 \mathrm{~km}, \mathrm{SE}=0.500$ ) than for the morning ones (1.23 sightings/100 km, $\mathrm{SE}=0.377)$, although these differences were not significant $(\mathrm{W}=10, P=0.625$; Wilcoxon signed rank test). However, from April to August, the number of sightings was higher in the morning censuses (Fig. 5).

\section{Wildcat activity patterns on pastures}

We tracked 20 of the 24 possible hourly segments (we did not track from 1:00 a.m. to 5:00 a.m.;), with an average of 27 censuses per hour (range $=6-51$ ). Wildcats were observed
Fig. 5 Monthly IKA values (number of sightings of wildcat $/ 100 \mathrm{~km}$ traveled) for the censuses carried out between March 2017 and February 2018

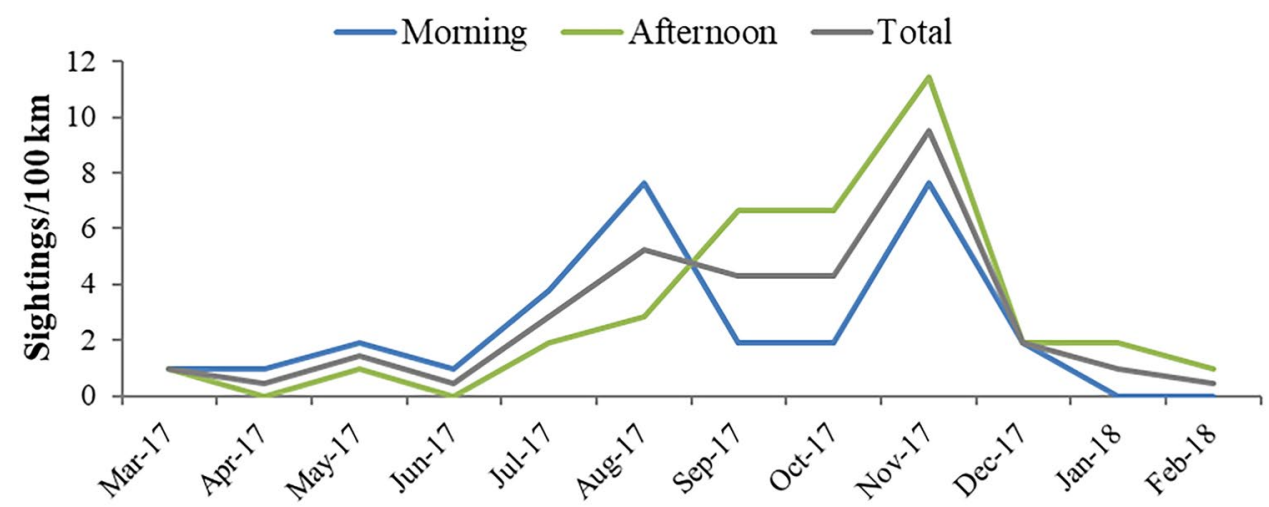

Months 
Fig. 6 Wildcat daily activity patterns on pastures at Montaña Palentina Natural Park. There were no data between 2:00 and 4:00. The activity index is the number of times a wildcat was sighted divided by the total number of times a census was undertaken for that hourly interval. Vertical discontinuous lines represent the sunrise and sunset intervals throughout the year

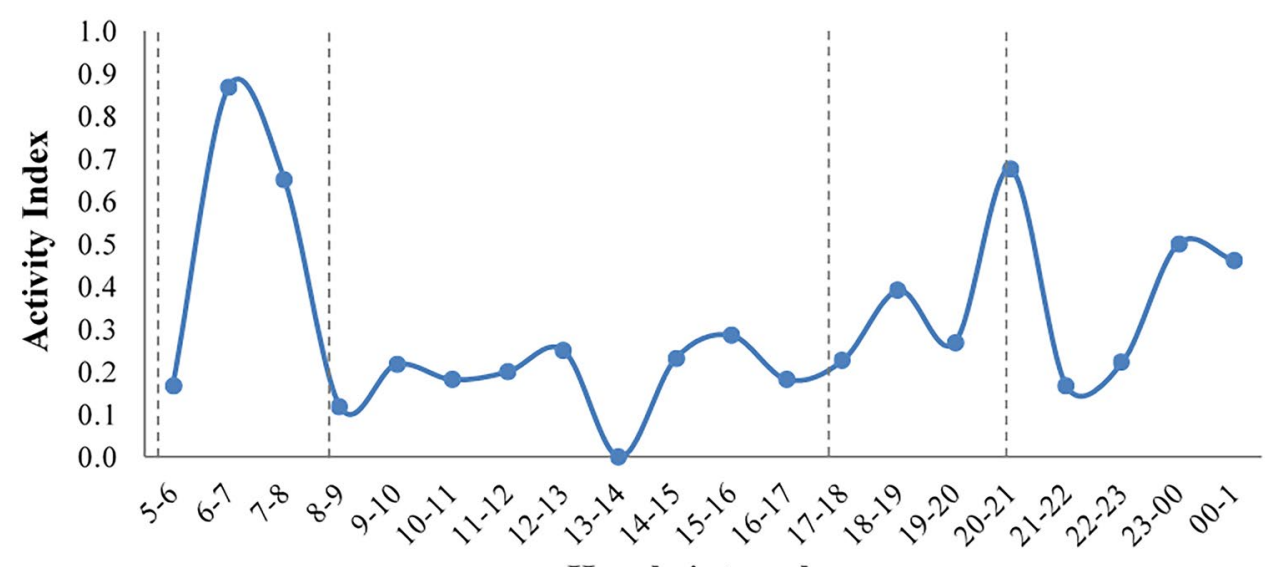

Hourly interval on pastures at all times of the day, although there was a higher probability of observation between 6:00 and 7:00, and between 20:00 and 21:00 (Fig. 6), especially shortly after sunrise $(54.6 \%$ of cats observed during the morning census were observed $1 \mathrm{~h}$ after sunrise) and earlier than sunset (48.7\% of cats observed during the afternoon were seen $1 \mathrm{~h}$ before sunset; Fig. 7).

\section{Discussion}

This is the first study where wildcats, a quite often considered forest species, are often recorded using an open habitat, the pasture areas of an ancient human-modified landscape for cattle. We were able to direct count wildcats in fix transects from a car, and found that wildcats mainly
Fig. 7 Percentage of observed wildcats in relation to sunrise (top panel) and sunset (bottom panel) times
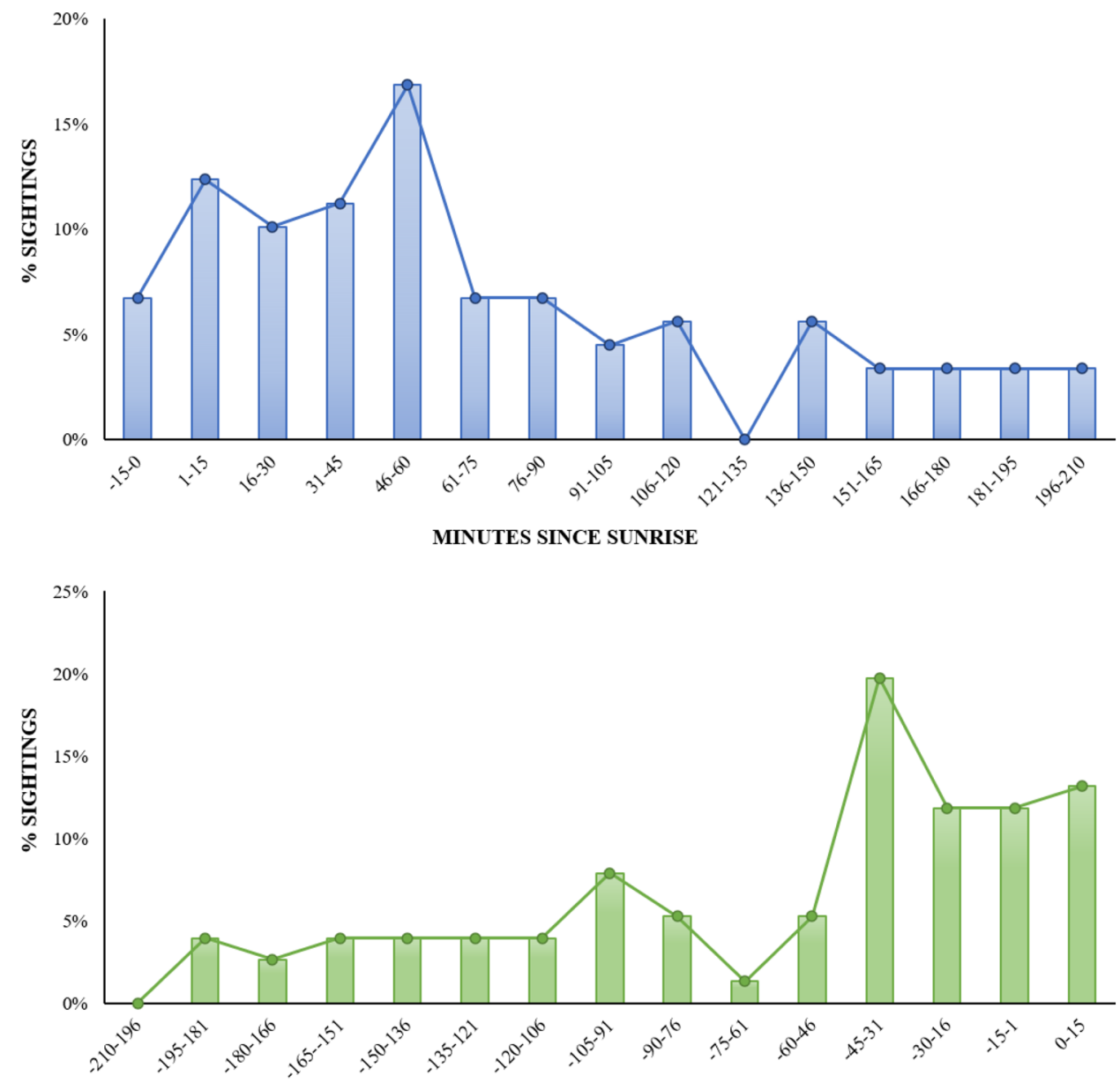

MINUTES BEFORE SUNSET 
used this habitat from July to November and even during daylight, although most records were in times close to sunset and sunrise.

The fact of being able to census wildcats on daylight in this open habitat could potentially allow to use individual identification by coat patterns and traditional capturerecapture models (O'Connell et al. 2010) or Bayesian spatially explicit capture-recapture (SECR; Broekhuis and Gopalaswamy 2016) to estimate abundance without the need to mark and recapture animals. These methods are utilized to study felids, which usually have striped or spotted coat patterns that allow individual identification (e.g., tigers Panthera tigris, Karanth et al. 2006, leopards Panthera pardus, Henschel and Ray 2003, snow leopards Panthera uncia, Jackson et al. 2006, jaguars Panthera onca, Maffei et al. 2004, Iberian lynx, Garrote et al. 2010, wildcats, Anile et al. 2010, Soto and Palomares 2014, cheetah Acinonyx jubatus, Broekhuis et al. 2021, or lions Panthera leo, Gogoi et al. 2020). However, in our case, we were able to individualize wildcats only for $30 \%$ of records, and thus, it was not possible to use capture-recapture methods to estimate wildcat abundance. Very often, wildcats in the study area are observed farther than $50 \mathrm{~m}$ (on average $95 \pm 76 \mathrm{~m}$, range $=0-342$; Rodríguez et al. 2020), which prevented sharp images in many cases. The use of adequate longdistance photographic equipment would have helped with this issue, and this method could still be used since wildcats mostly behave calmly and are observed over long periods.

Unlike other areas where wildcats are almost impossible to see, direct counts have proved to be a feasible method to estimate relative wildcat abundance in our study area, where wildcats are using open pastures mainly to hunt montane water voles (Jubete et al. 2017; Rodríguez et al. 2020), a small mammal species that is considered as pest in many areas (Delattre and Giraudoux 2009). With relatively little human effort and few resources, we were able to count between 14 and 43 wildcats during a weeklong period in the summer season. Domestic cats were also seen during samplings in pastures, but they were always clearly distinguished from the putative wildcats (Rodríguez et al. 2020). We never observed a cat with appearance of being a hybrid, which might be related to the fact that domestic cats were normally seen close to human habitations, whereas wildcats were close to forests; they used different strategies of pasture use probably to prevent aggressive interactions with foxes, Vulpes vulpes, and other canids (Rodríguez et al. 2020; also see Ruiz-Villar et al. 2021). Nevertheless, it is well known that hybrid may hardly be distinguished from pure wildcats without genetic confirmation (Devillard et al. 2014). Taking into consideration the results of this study, some improvements could easily be incorporated for censuses. First, censuses over a complete year indicated that wildcats mainly use pastures between August and November, and thus, censuses focused on monitoring the use of pastures by wildcats along years should be carried out during this season. Second, to concentrate censuses only in the hour before sunset or after sunrise would save time allocated to censuses. Third, although in some cases the number of wildcats sighted was slightly higher during the night and early morning, we recommend observations be carried out in the afternoon, when the number of cats observed was more stable, and may better reflect the use over time of pastures by cats.

The IKA does not account for imperfect detection, so we could not estimate absolute wildcat abundance. However, IKA does still allow to monitor the same population over time and between seasons (Kendall et al. 1992; Pellerin et al. 2017). Nevertheless, in our case, some reasonable doubt remains about it that was possible to accurately measure actual population trends. Cattle pastures have an attraction effect on wildcats, because these areas may contain a higher density of wildcat prey, such as montane water voles (Lozano et al. 2006; Palomo et al. 2007). In fact, we observed on many occasions wildcats hunting them during censuses (Jubete et al. 2017). Therefore, our estimations may reflect the use by wildcats of cattle pastures over years and seasons rather than estimating actual relative abundance in the whole area. In this case, we could be facing a scenario similar to the one found by Lozano (2009) in the central Iberian Peninsula, in an area with crops and Mediterranean vegetation, where wildcat populations were stable on a regional scale while they varied at a local one.

Normally, we observed wildcats engaging in clear hunting behavior during censuses, and therefore, wildcat use of cattle pastures may be related to montane water vole abundance or availability rather than to the actual felid abundance. This idea that our data may indicate wildcat use of pastures as a function of montane water vole abundance or availability rather than actual abundance of wildcats in the area is supported by our censuses of this small mammal in the area. We found a decline in montane water vole abundance during 2018 and 2019 (authors, unpublished data), coinciding with a lower number of wildcats recorded on pastures. Nonetheless, we are confident that our data provide accurate and actual abundance of wildcats on pastures.

Although we did not sample for abundance of montane water voles over a complete year, it is known that during winter, they stop reproduction and their abundance peaks in summer-autumn (Ventura and Gosalbez 1990), which explains why we observed a lower number of cats on pastures between December and June, and a higher number between July and November. Nevertheless, other reasons could be contributing to the observed pattern of wildcat presence on pasture along the year. Wildcat estrus takes place more frequently between January and March (Nowell and Jackson 1996), and births occur approximately 2 months 
later (Stahl and Léger 1992) during April and May. Cubs become independent in autumn-winter, at 5 months of age, a time of the year when dispersing animals also explore new areas (Sundquist and Sundquist 2002). Thus, during winter and spring, wildcats, mainly males, present higher mobility during mating and confinement in the case of breeding females, which may decrease the time animals spent on visible pastures. Furthermore, during summer and autumn, breeding females would need to use more pastures for hunting, and the year's young and dispersing animals would also start to use pastures more often, thus increasing the number of animals that may be observed on pastures. We cannot discard the possibility that these factors may also be contributing to the visibility of wildcats on pastures. Additionally, the visibility of pastures is not homogeneous throughout the year, and during May, July, and part of July, it is lower due to the presence of tall grasses (between 30 and $60 \mathrm{~cm}$ ).

Contrary to expectation, the wildcat daily activity patterns we found in cattle pastures is similar to this known in other areas. Daily activity, or daily use of cattle pastures, is concentrated around sunrise and sunset, but wildcats may be active throughout the 24-h period as observed in other localities (Liberek 1999; Monterroso et al. 2014; MartinDíaz et al. 2018). Montane water voles (the main prey sought by wildcats in pastures of the study area), from spring to autumn, may be active for feeding and underground tunnel maintenance close to the pasture surface at any time of the day (Airoldi 1979). However, juvenile dispersion, which is realized above ground, occurs mainly on rainy nights (Saucy and Schneiter 1997).

Populations throughout Europe seem to be decreasing, but there is actually scarce information about wildcat population trends, so this inference is mainly based on increases in threats (Yamaguchi et al. 2015). In some regions, the species are extending its geographic range and heterogeneous landscapes with forest and open land seem to have a key role in maintaining and spreading of the wildcat populations (Mueller et al. 2020). In this context, the ancient humantransformed landscape for cattle pastures in northern Iberian Peninsula is an important habitat for wildcat conservation, and to keep this traditional low-intensity use of soil should be maintained, including maintenance of shrubs and forest vegetation in hedges, stream, and rivers. This traditional use of landscape is threatened in the region due to projects of land consolidation. The transformation implies property grouping, which reduces and channels streams, removes hedges, and dries up small bogs and wetlands (GEA 2007; Jubete and Román 2016). Furthermore, our results (this study and Rodríguez et al. 2020) show that wild and domestic cats are using the same pastures for hunting; therefore, it exists the potential for diseases transmission and hybridization. A management plan for domestic cats should be implemented in order to prevent both facts, which should include vaccine campaigns (e.g., against the leukemia feline) and sterilization, at least in domestic cats moving outside buildings in the areas reported in this study of higher frequency of use by wildcats. Finally, most pastures used intensively by wildcats for hunting are in the bottom of valleys (Fig. 1), where road also run; therefore, the risk for road accidents is high. In fact, at least two out of six GPS-collared wildcats in the area were killed by cars, just one and 4 months after being tagged (authors unpublished information). Thus, building under and over passes for wildlife, fencing roads, and/or establish low speed limits in the areas intensively used by wildcat should implement measures to prevent wildcat road accidents.

Acknowledgements We are very grateful to Laura Benito, Juan Ángel de la Torre, Alberto Pezonaga, Gema Ruiz, and Juana Guzón for helping during fieldwork.

Funding Open Access funding provided thanks to the CRUE-CSIC agreement with Springer Nature. This study was partially supported by M. Torres Diseños Industriales SAU and Jaguar Land Rover España.

Availability of data and material The datasets generated during the current study are available in the DIGITAL.CSIC repository, http:// hdl.handle.net/10261/215160.

Code availability All software is cited in the manuscript.

\section{Declarations}

Ethics approval This study does not need any ethic approval since there is no animal experimentation or management.

Consent to participate All authors agreed to participate in this study and co-authorship.

Consent for publication All authors agreed to participate in this study and co-authorship.

Conflict of interest The authors declare have no competing interests.

Open Access This article is licensed under a Creative Commons Attribution 4.0 International License, which permits use, sharing, adaptation, distribution and reproduction in any medium or format, as long as you give appropriate credit to the original author(s) and the source, provide a link to the Creative Commons licence, and indicate if changes were made. The images or other third party material in this article are included in the article's Creative Commons licence, unless indicated otherwise in a credit line to the material. If material is not included in the article's Creative Commons licence and your intended use is not permitted by statutory regulation or exceeds the permitted use, you will need to obtain permission directly from the copyright holder. To view a copy of this licence, visit http://creativecommons.org/licenses/by/4.0/. 


\section{References}

Airoldi JP (1979) Etude du rythme d'activite du campagnol terrestre. Arvicola Terrestris Scherman Shaw Mammalia 43(1):25-52

Agencia Estatal de Meteorología (2020) Valores normales para el período de referencia 1981-2010. Recovered May 7th 2020 in https://opendata.aemet.es

Anile S, Amico C, Ragni B (2012) Population density estimation of the European wildcat (Felis silvestris silvestris) in Sicily using camera trapping. Wildlife Biol 8:1-12

Anile S, Bizzarri L, Ragni B (2010) Estimation of European wildcat population size in Sicily (Italy) using camera trapping and capture-recapture analyses. Ttal J Zool 77:241-246

Anile S, Devillard S, Ragni B, Rovero F, Mattucci F, Valvo ML (2019) Habitat fragmentation and anthropogenic factors affect wildcat Felis silvestris silvestris occupancy and detectability on Mt Etna. Wildlife Biol 2019(1)

Anile S, Ragni B, Randi E, Mattucci F, Rovero F (2014) Wildcat population density on the Etna volcano, Italy: a comparison of density estimation methods. J Zool 283:252-261

Beugin MP, Leblanc G, Queney G, Natoli E, Pontier D (2016) Female in the inside, male in the outside: insights into the spatial organization of a European wildcat population. Conserv Genet 17(6):1405-1415

Broekhuis F, Elliot NB, Keiwua K, Koinet K, Macdonald DW, Mogensen N, Thuo D, Gopalaswamy AM (2021) Resource pulses influence the spatio-temporal dynamics of a large carnivore population. Ecography 44:358-369. https://doi.org/10.1111/ecog.05154

Broekhuis F, Gopalaswamy AM (2016) Counting cats: spatially explicit population estimates of cheetah (Acinonyx jubatus) using unstructured sampling data. PLoS One 11:e0153875

Canters KJ, Thissen JB, van Diepenbeek A, Jansman HA, Goutbeek $\mathrm{K}$ (2005) The wildcat (Felis silvestris) finally recorded in the Netherlands. Lutra 48(2):67

Council Directive 92/43/EEC of 21 May 1992 on the conservation of natural habitats and of wild fauna and flora. OJEU 206:7-50

Council of Europe (1979) Convention on the Conservation of European Wildlife and Natural Habitats https://www.coe.int/en/web/conventions/ full-list//conventions/treaty/104 (03 December 2020)

Delattre P, Giraudoux P (2009) Le campagnol terrestre. Prévention et contrôle des populations. Éditions Quae, Cedex

Devillard S, Jombart T, Léger F, Pontier D, Say L, Ruette S (2014) How reliable are morphological and anatomical characters to distinguish European wildcats, domestic cats and their hybrids in France? J Zoolog Syst Evol Res 52:154-162. https://doi.org/ 10.1111/jzs.12049

Ferry C, Frochot B (1958) Une méthode pour dénombrer les oiseaux nicheurs. Revue d'écologie 85-102

Gabinete de Estudios Ambientales - GEA (2007) Incidencia de la concentración parcelaria en la evolución socioeconómica de municipios del norte de Palencia. Fundacion Para La Defensa De La Cordillera Cantabrica

García-Perea R (2007) Felis silvestris Schreber, 1777. In: Palomo J, Gisbert J, Blanco JC (eds.) Atlas y libro rojo de los mamíferos de España. Dirección General para la Biodiversidad-SECEM -SECEMU, Málaga, pp 333-335

Garrote G, Perez de Ayala R, Pereira P et al (2010) Estimation of the Iberian lynx (Lynx pardinus) population in the Doñana area, SW Spain, using capture-recapture analysis of camera-trapping data. Eur J Wild Res 57(2):355-362

Gil-Sánchez JM, Barea-Azcón JM, Jaramillo J, Herrera-Sánchez FJ, Jiménez J, Virgós E (2020) Fragmentation and low density as major conservation challenges for the southernmost populations of the European wildcat. PLoS One. https://doi.org/10.1371/journal. pone. 0227708
Gil-Sánchez JM, Jaramillo J, Barea-Azcón JM (2015) Strong spatial segregation between wildcats and domestic cats may explain low hybridization rates on the Iberian Peninsula. Zool 118(6):377-385

Gogoi K, Kumar U, Banerjee K, Jhala YV (2020) Spatially explicit density and its determinants for Asiatic lions in the Gir forests. PLoS One 15:e0228374. https://doi.org/10.1371/journal.pone. 0228374

Henschel P, Ray J (2003) Leopards in African rainforests: survey and monitoring techniques. WCS, New York

Jackson RM, Roe JD, Wangchuk R, Hunter DO (2006) Estimating snow leopard population abundance using photography and capturerecapture techniques. Wildl Soc Bull 34(3):772-781

Jerosch S, Götz M, Roth M (2017) Spatial organisation of European wildcats (Felis silvestris silvestris) in an agriculturally dominated landscape in Central Europe. Mamm Biol 82(1):8-16

Jerosch S, Kramer-Schadt S, Götz M, Roth M (2018) The importance of small-scale structures in an agriculturally dominated landscape for the European wildcat (Felis silvestris silvestris) in central Europe and implications for its conservation. J Nat Conserv 41:88-96

Jubete F, Román J (2016) New large threatened population of (Phengaris nausithous) discovered in the SW of Europe. J Insect Conserv 20:155-158

Jubete F, Urra F, Palomares F, Román J, Revilla E (2017) Desarrollo de un protocolo de monitorización del gato montés en la Montaña Palentina. XII Congreso de la SECEM, Málaga

Karanth KU, Nichols JD, Kumar NS, Hines JE (2006) Assessing tiger population dynamics using photographic capture-recapture sampling. Ecology 87:2925-2937

Kendall KC, Metzgar LH, Patterson DA, Steele BM (1992) Power of sign surveys to monitor population trends. Ecol Appl 2(4):422-430

Kéry M, Gardner B, Stoeckle T, Weber D, Royle JA (2011) Use of spatial capture-recapture modeling and DNA data to estimate densities of elusive animals. Conserv Biol 25(2):356-364

Klar N, Fernández N, Kramer-Schadt S, Herrmann M, Trinzen M, Büttner I, Niemitz C (2008) Habitat selection models for European wildcat conservation. Biol Conserv 141(1):308-319

Lapini L, Molinari P (2007) Nach zehn Jahren taucht in Kärnten die Wildkatze (Felis s. silvestris Schreber 1777: Mammalia: Felidae) wieder auf. Carinthia II 117:59-66

Liberek M (1999) Eco-ethologie du chat sauvage Felis s. silvestris, Schreber 1777 dans le Jura Vaudois (Suisse): Influence de la couverture neigeuse. Dissertation, Université de Neuchâtel

Lozano J (2009) Ecología del gato montés ("Felis silvestris") y su relación con el conejo de monte ("Oryctolagus cuniculus"). Dissertation, Universidad Complutense de Madrid

Lozano J (2010) Habitat use by European wildcats (Felis silvestris) in central Spain: what is the relative importance of forest variables? Anim Conserv 33(2):143-150

Lozano J (2017) Gato montés - Felis silvestris. In: Salvador A, Barja I (eds.) Enciclopedia Virtual de los Vertebrados Españoles. Museo Nacional de Ciencias Naturales, Madrid

Lozano J, Moleón M, Virgós E (2006) Biogeographical patterns in the diet of the wildcat, Felis silvestris Schreber, in Eurasia: factors affecting the trophic diversity. J Biogeogr 33:1076-1085

Maffei L, Cuéllar E, Noss A (2004) One thousand jaguars (Panthera onca) in Bolivia's Chaco? Camera trapping in the Kaa-Iya National Park. J Zool 262:295-304

Martin-Díaz P, Gil-Sánchez JM, Ballesteros-Duperón E, Barea-Azcón E, Virgós E, Pardavila X, Moleón M (2018) Integrating space and time in predator-prey studies: the case of wildcats and rabbits in SE Spain. Mamm Biol 88:114-122

Monterroso P, Alves P, Ferreras P (2014) Plasticity in circadian activity patterns of mesocarnivores in Southwestern Europe: implications for species coexistence. Behav Ecol Sociobiol 68(9):1403-1417 
Monterroso P, Brito JC, Ferreras P, Alves PC (2009) Spatial ecology of the European wildcat in a Mediterranean ecosystem: dealing with small radio-tracking datasets in species conservation. J Zool 279(1):27-35

Mueller SA, Reiners TE, Steyer K, von Thaden A, Tiesmeyer A, Nowak C (2020) Revealing the origin of wildcat reappearance after presumed long-term absence. Eur J Wildl Res 66(6):1-8

Nowell K, Jackson P (1996) The wild cats: status survey and conservation action plan. IUNC/Cat Specialist Group, Gland

O'Connell AF, Nichols JD, Karanth KU (2010) Camera traps in animal ecology: methods and analyses. SSBM, Luxemburgo

Oliveira T, Urra F, López-Martín JM (2018) Females know better: sex-biased habitat selection by the European wildcat. Ecol Evol 8(18):9464-9477

Palomo LJ, Gisbert J, Blanco JC (2007) Atlas y libro rojo de los mamíferos terrestres de España. Dirección General para la Biodiversidad SECEM-SECEMU, Málaga

Pellerin M, Bessière A, Maillard D, Capron G, Gaillard JM, Michallet J, Bonenfant C (2017) Saving time and money by using diurnal vehicle counts to monitor roe deer abundance. Wildl Biol 2017(4)

Rodríguez A, Urra F, Jubete F, Román J, Revilla E, Palomares F (2020) spatial segregation between red foxes (Vulpes vulpes), European wildcats (Felis silvestris) and domestic cats (Felis catus) in pastures in a livestock area of Northern Spain. Diversity 12:268. https://doi.org/10.3390/d12070268

Ruiz-Villar H, Jubete F, Revilla E, Román J, Urra F, López-Bao JV, Palomares F (2021) Like cat and fox: diurnal interactions between two sympatric carnivores in pastoral landscapes of NW Spain. Eur J Wildl Res 67:16. https://doi.org/10.1007/s10344-021-01469-3

SAS Institute INC (2018) SAS/STAT User's Guide, Version 15.1, edn. SAS Institute, Cary

Saucy F, Schneiter B (1997) Juvenile dispersal in the vole Arvicola terrestris during rainy nights: a preliminary report. Bull De La Soc Vaud Des Sci Nat 84(4):333-345
Say L, Devillard S, Léger F, Pontier D, Ruette S (2012) Distribution and spatial genetic structure of European wildcat in France. Anim Conserv 15(1):18-27

Schauenberg P (1981) Éléments d'écologie du chat forestier d'Europe Felis silvestris Schreber, 1777. Revue d'écologie

Silva AP, Kilshaw K, Johnson PJ, Macdonald DW, Rosalino LM (2013) Wildcat occurrence in S cotland: food really matters. Divers Distrib 19(2):232-243

Soto CA, Palomares F (2014) Surprising low abundance of European wildcats in a Mediterranean protected area of southwestern Spain. Mammalia 78(1):5765

Stahl PR, Léger F (1992) Le chat sauvage d'Europe:(Felis silvestris Schreber, 1777). Société française pour l'étude et la protection des mammifères, Bourges

Steyer K, Kraus RH, Mölich T et al (2016). Large-scale genetic census of an elusive carnivore, the European wildcat (Felis s. silvestris). Conserv Genet 17(5): 1183-1199

Sundquist M, Sundquist F (2002) Wild cats of the world. University of Chicago press, Chicago

Urra F (2003) El gato montés en Navarra: distribución, ecología y conservación. PhD Dissertation, Autonomous University of Madrid

Ventura J, Gosalbez J (1990) Reproductive cycle of Arvicola terrestris (Rodentia, Arvicolidae) in the Aran Valley, Spain. Z Saugetierkd 55:383-391

Yamaguchi N, Kitchener A, Driscoll C, Nussberger B (2015) Felis silvestris. The IUCN Red List of Threatened Species 2015: e.T60354712A50652361. https://doi.org/10.2305/IUCN.UK. 2015-2.RLTS.T60354712A50652361.en

Publisher's Note Springer Nature remains neutral with regard to jurisdictional claims in published maps and institutional affiliations. 